\title{
Biodegradation of new polymer foundry binders composition of poly(acrylic acid)/dextrin**)
}

\begin{abstract}
Summary - Investigations were carried out focusing on novel polymeric binders and their susceptibility to biodegradation. As an example a water-soluble composition of poly(acrylic acid)/dextrin is presented. Determination of the total oxygen demand for biodegradation has been accomplished under laboratory conditions, in accordance with the static water test system (the Zahn-Wellens method). In that system the mixture in which the biodegradation takes place contains activated sludge as the inorganic nutrient and the investigated polymeric composition designed to be the exclusive source of carbon and energy. The progressively increasing biodegradation has been tested by means of the chemical oxygen demand and by the simultaneously determined degree of biodegradation $R_{t}$. These investigations have proven the poly(acrylic acid)/dextrin composition to be a material fully biodegradable in water. This statement is justified by degree of biodegradation $R_{t}=65 \%$ which occurred on the 28 th day of testing. At the same time a separate sample of the crosslinked polymeric composition was tested on the biodegradation resulting from storing the sample for over 6 months in garden soil. During that time several analyses were performed by means of the Raman spectroscopy, optical microscopy and atomic force microscopy (AFM). The intention was to study structural changes on surfaces resulting from the degradation. Keywords: polymer binders, molding sands, polymer composition, biodegradation.
\end{abstract}

BIODEGRADACJA NOWYCH POLIMEROWYCH SPOIW ODLEWNICZYCH NA PRZYKŁA-
DZIE KOMPOZYCJI POLI(KWAS AKRYLOWY)/DEKSTRYNA Streszczenie - Przedstawiono badania biodegradacji nowego polimerowego spoiwa odlewniczego - wodorozpuszczalnej kompozycji poli(kwas akrylowy)/dekstryna. Degradacje prowadzono w środowisku wodnym lub w glebie. Oznaczenie całkowitej tlenowej biodegradacji w środowisku wodnym wykonano $\mathrm{w}$ warunkach laboratoryjnych, zgodnie ze statycznym wodnym systemem testowym metodą Zahna-Wellensa. Poddana biorozkładowi mieszanina zawierała pożywkę nieorganiczna, osad czynny oraz kompozycję polimerową, stanowiącą jedyne źródło węgla i energii. Postęp biorozkładu próbki w środowisku wodnym oceniano na podstawie wartości chemicznego zapotrzebowania tlenu (ChZT) oraz stopnia biodegradacji $\left(R_{t}\right)$, mierzonych w przygotowanych mieszaninach $w$ trakcie trwania testu. Przeprowadzone badania wykazały, że kompozycja poli(kwas akrylowy)/dekstryna jest materiałem w pełni biodegradowalnym $\mathrm{w}$ środowisku wodnym. Wyznaczony w ostatnim, 28 dniu trwania testu stopnień biodegradacji $\left(R_{t}\right)$ osiagnął poziom $65 \%$, co wg przyjętych norm oznacza, iż badaną kompozycję polimerową można uznać za w pełni biodegradowalną. Próbki usieciowanej kompozycji polimerowej poddawano, trwającej 6 miesięcy biodegradacji w glebie ogrodowej. Zmiany powierzchniowe oraz strukturalne wynikające z rozkładu próbki analizowano metodą spektroskopii Ramana oraz mikroskopii AFM i mikroskopii optycznej.

Słowa kluczowe: spoiwa polimerowe, masy odlewnicze, kompozycja polimerowa, biodegradacja.

\footnotetext{
1) AGH - University of Science and Technology, Faculty of Foundry Engineering, Reymonta 23, 30-059 Krakow, Poland.

2) Jagiellonian University, Faculty of Chemistry, Ingardena 3, 30-060 Krakow, Poland.

3) AGH - University of Science and Technology, Faculty of Materials Science and Ceramics, Mickiewicza 30, 30-059 Krakow, Poland.

*) Author for correspondence; e-mail: beata.grabowska@agh.edu.pl

**) Material contained in this article was presented at the $54^{\text {th }}$ Annual Congress of PTChem and SITPChem, Polymer Section, Lublin, Poland, 18-22 September 2011.
} 


\section{INTRODUCTON}

From the chemical point of view molding sand constitutes a mixture of several chemical substances - molding materials, selected in proper ratios and mixed in the determined way. The main loose constituent of molding sand is its matrix of a determined mineralogical, chemical and grain composition (most often it is high-silica sand). The binding material is the component, which has the ability of gluing matrix grains and causes that a loose matrix obtains the defined mechanical strength. This binding material can be of a mineral origin (e.g. bentonite), inorganic (e.g. water-glass) or organic, such as resins (e.g. phenolic). The selection of the proper way of the binder cross-linking in the sand (molding sand hardening) to achieve the binding power in the binder-matrix system should be sufficient to maintain the mould shape during pouring it with a liquid metal. The molding sand hardening process can be performed by physical agents (e.g. temperature) or chemical (e.g. amine, $\mathrm{SO}_{2}$ or $\mathrm{CO}_{2}$ ). After the hardening of molding sand in the mould, a liquid metal is poured (ferrous alloys or non-ferrous metal alloys) into its cavity and after the metal solidification the mould is knocked-out and the casting is obtained [1,2].

Molding sands used for making moulds, reproducing shape of the given element (casting), differ in their composition, way of binding and consistence. They are intended for various aims not only from the point of view of components used for castings (cast steel, cast iron, non-ferrous metals), but also in respect of application at molding (mould parts, cores).

Polymer binders are also used in the foundry technology as binding materials for molding core sands [3]. Polymer binders contain only synthetic or natural polymers dissolved in the properly selected solvent.

There are a few commonly used synthetic polymers (polystyrene, polysiloxane, polyacrylate of sodium and polyacrylic acid) in foundry practice. Numerous papers dealing with the development of binders and processes using biopolymers and their derivatives can be also found $[4-6]$.

There are increasing demands within the engineering of foundry processes, related to technical, ecological and economic parameters of binding materials. This fact implies the development of new technologies utilizing new binding agents and research on the explanation of accompanying crosslinking as well as degradation processes. This knowledge facilitates planning and control of the process and obtaining - at the final technological stage - the sand casting of the required dimensions [7].

In the Laboratory of Environmental Protection of the Faculty of Foundry Engineering, AGH, the research concerning applications of new polymer binders of molding sands has been carried out. Within these investigations the new water soluble binders containing biopolymers were worked out. These binders are polymer compositions in a form of water solutions of natural (polysaccha- rides) and synthetic (polyacrylates) polymers. They are characterized by several desired physicochemical and technological properties, due to which they can become a serious alternative of organic binders for molding and core sands $[8,9]$. Experimental tests performed in the foundry confirmed the positive laboratory results on applications of the polymer compositions as molding sands binders, and the obtained iron castings fulfilled all qualitative requirements [10].

However, the binding materials should not only meet the technological standards, but also should not generate hazards to the environment during the technological process of the molding sand preparation, casting mould production and pouring this mould with a liquid metal (making casting), as well as during further storing of the spent molding sands. The knowledge of the influence of spent molding sands, stored in dumping grounds, on the environment in the context of their biodegradation is still limited. It can be expected that the biological degradation process of the polymer binder will proceed in accordance with the generally assumed mechanism of the biological degradation of polymers [11-14]. This mechanism is based on the decomposition of the polymer material in the environment within at the reasonable time after its utilization. The process involves activities of microorganisms such as bacteria, fungi or algae under conditions favoring their growth, thus in the presence of oxygen, mineral nutrients and at a proper humidity, temperature and $\mathrm{pH}$. An essential factor decisive for the bio-decomposition possibility stems from the chemical constitution of the polymer binder, which contains polar functional groups such as hydroxyl and carboxylicones. In order to broaden the knowledge on the biodegradability of the polymer foundry binders, the biodegradation process of the novel polymer binder consisting of poly(acrylic acid) (PAA) and dextrin (D) was investigated in the water environment and in soil.

\section{EXPERIMENTAL}

\section{Materials}

A new polymer binder in a form of a water solution was provided by the two-component polymer composition (PAA/D). The composition was obtained by mixing in water the synthetic polymer - poly (acrylic acid) (PAA) [Sokalan PA80S, BASF, molar mass: $100000 \mathrm{~g} / \mathrm{mol}$, concentration: $35 \%$, pH 1.5, viscosity: $1000 \mathrm{mPa} \cdot \mathrm{s}$, Formula (I)] with the natural polymer D [Dextrin from potato, Fluka, Formula (II)] in a weight ratio 1:1.

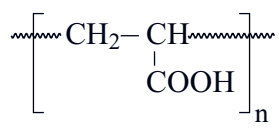

(I)

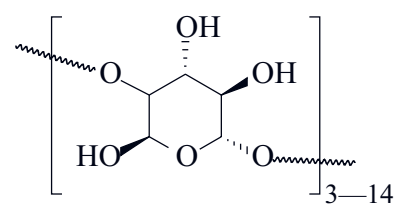

(II) 


\section{Crosslinking of the polymer binder}

Crosslinking of samples by microwaves was carried out in the microwave reactor RM 2001 Pc from Plazmatronika Company. The microwave device was equipped with an electronic system for temperature regulation inside the reactor as well as for regulation of the time factor and power supply. Samples were subjected to microwaves operations with the power of $800 \mathrm{~W}$ lasting without interruption for $90 \mathrm{~s}$. The temperature inside the device during the radiation was approximately $150{ }^{\circ} \mathrm{C}$.

\section{Investigations of the biodegradation in aqueous solution}

Biodegradation examinations in water environment were carried out on the basis of the static test [Zahn-Wellens method, PN-EN ISO 9888 (2005)]. Susceptibility of non-volatile, water soluble organic substances (concentration range of $50-400 \mathrm{mg} / \mathrm{dm}^{3}$ during the static testing) was the subject of estimation.

The method may be applied only if organic substances are used in the test which substances:

- should dissolve in water under experimental conditions,

- should not hamper bacteria growth,

- should exhibit very low vapor pressure under experimental conditions,

- should be adsorbed in the testing system only to a limited extent.

The biodegradation process was performed in vessels $\left(1 \mathrm{dm}^{3}\right)$ equipped with a device for mixing and aerating. Mixtures containing: activated sludge (microorganisms), nutrient components (basic solution for bacteria) as well as water solutions of samples submited the biodegradation as the sole carbon source were placed in such vessels. Concentration of samples was within the range of $50-400 \mathrm{mg} / \mathrm{dm}^{3}$.

The incubation process lasted 28 days, and according to recommendations was carried out in darkness, maintaining an ambient temperature, between $20-25^{\circ} \mathrm{C}$, the mixture aeration amounted to app. $8 \mathrm{mg} \mathrm{O} / \mathrm{dm}^{3}$.

The following samples were subjected to the biodegradation:

- ethylene glycol (GE) as a standard (reference value of the biodegradation degree $>90 \%$ ), POCh;

- polymer of a natural origin: D (dextrin);

- synthetic polymer: PAA [poly(acrylic acid)];

- polymer composition: PAA/D;

- reference sample $(\mathrm{O})$ containing only activated sludge and nutrient components (blank test).

\section{Investigations of the biodegradation in a soil}

A sample of the polymer composition, crosslinked by microwaves action was placed in a garden soil in such a way that a part of the sample was under the soil surface at the depth of $2 \mathrm{~cm}$ and another part above the surface. The biodegradation was carried out under conditions mimicking the natural ones, under which the majority of foundry waste is degraded (waste dumping grounds), at environmental temperature and a moderate soil moistness (app. $25 \%$ ). The biodegradation process in a soil lasted for over 6 months, after which the sample underwent structural and thermal analysis.

\section{Methods of testing}

\section{Measurements of the Chemical Oxygen Demand (COD)}

The biodecomposition process was monitored within the determined time intervals for over 28 days by performing the spectrophotometric determination of the chemical oxygen demand (COD), in accordance to recommendations of the standard procedure concerning the COD [PN-ISO 15705 (2005)].

Changes in biodegradation degrees $\left(R_{t}\right)$ of the samples were estimated during the biodegradation on the basis of COD following the Zahn-Wellens method. The ratio of the COD value (lower after each interval) determined at the beginning of the experiment, to the value determined every 3 hours, provided the biodecomposition $R_{t}$ factors.

Atomic Force Microscope (AFM) Atomic Force Microscope (AFM) (Picoforce, Veeco, USA) working in a tapping mode was used to characterize surfaces exposed to air. Standard silicon cantilevers (Veeco) with a nominal spring constant $40 \mathrm{~N} / \mathrm{m}$ and the tip radius $<10 \mathrm{~nm}$ were used for all measurements.

Optical microscope: Nikon Eclipse LV 100 with variable objectives and equipped with color CCD camera was used to capture microscopic images.

\section{Raman spectroscopy}

Measurements were made with the Fourier Transform Spectroscope, FTS 6000 of the American Bio-Rad Company with a FT - Raman attachment. Measuring parameters: laser power on a sample $120 \mathrm{~mW}$, resolution $4 \mathrm{~cm}^{-1}$, measuring range $4000-80 \mathrm{~cm}^{-1}$.

\section{RESULTS AND DISCUSSION}

\section{Biodegradation in water}

The biodecomposition process was monitored every day by checking $\mathrm{pH}$ changes, temperature and deaeration degree of the investigated samples. The measured $\mathrm{pH}$ value were constant - in accordance with the test recommendations - within $7-8$, during the whole period of the test. Other required conditions were also maintained (ambient temperature: $20-25^{\circ} \mathrm{C}$, aeration degree app. $8 \mathrm{mg} \mathrm{O}_{2} / \mathrm{dm}^{3}$ ).

In accordance with the test requirements the COD value was estimated in selected time intervals. The COD 


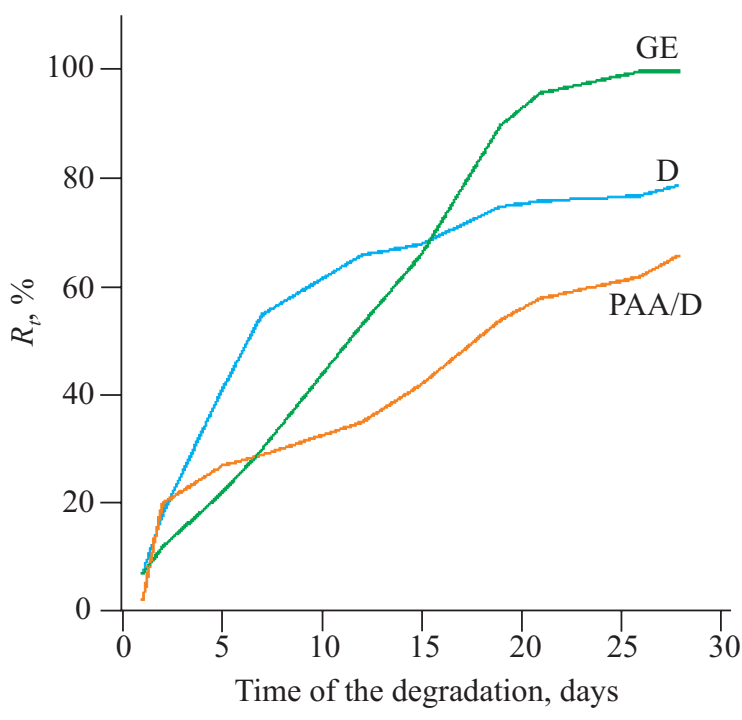

Fig. 1. Biodegradation curves

results (decreasing after each interval), versus the value determined after 3 hours from the moment of the test beginning provides the percentage biodegradation value.

The calculated $R_{t}$ values are presented in the graph as a function of the biodegradation time, providing the biodegradation curve (Fig. 1).

A polymer is considered to be biodegradable when its biodegradation degree after 28 days of a cycle reaches at least $60 \%$ [11]. This condition was satisfied by samples: $\mathrm{D}\left(R_{t}=80 \%\right)$ and PAA/D $\left(R_{t}=65 \%\right)$. Synthetic polymer PAA contained in the PAA/D sample rendered difficult its biodecomposition, however on the 28th day the required degree was obtained, what means that the investigated polymer composition can be considered as fully biodegradable. The PAA/D sample practically exceeded already on the 22nd day of the test the required biodegradation level.

An attempt to perform the biodecomposition process of poly(acrylic acid) (PAA) was undertaken, but in accordance with expectations, this substance caused an inhibition of the microorganisms metabolism which significantly increased the samples turbidity and its COD (more than 12 times) within three days. The reference GE sam- ple biodegraded practically in $100 \%$ on the 26th day of the test.

\section{Biodegradation in a soil}

A technological process leaves behind remarkable amounts of spent molding sands which are deposed in dumping grounds. For that reason it seemed advisable to subject the polymeric composition PAA/D to further investigations consisting first in crosslinking it by microwave radiation, and next in subjecting the crosslinked polymer to investigation on degradation in a sand.

The aim was to mimic conditions prevailing in dumping grounds. Microwave radiation causes changes in the structure of the prepared polymer composition.

The crosslinking here is physical in nature and takes place mainly due to evaporation of the physically bound water.

Consequently, the repeatedly dissolved polymer composition, by microwaves crosslinking, regains in water its previous properties what is a proof that microwaves cause a physical crosslinking only. That is clearly important in the biodegradation process.

One half the crosslinked polymer sample (PAA/D), was placed for six months in a garden soil, the other half was preserved for comparison. Visual changes caused by the biodegradation are evidenced in Fig. 2.

Morphological changes are visible only on this part of the surface which was in a soil (tarnish), while the part which did not contact with a soil remained without changes. Changes of the inner structure in a form of empty places are related to the advancing dextrin biodegradation, while the visible scratches are caused by presence of PAA. Thus, it seems that the sample placed in a soil undergoes gradual biodegradation. The passage of time caused tarnish formation on the PAA/D sample. It was the reason why the microscopic examinations have been performed additionally.

The surface roughness change of the PAA/D sample visible in AFM pictures (Fig. 3) before and after the 6 months of biodecomposition indicates, that the biodegradation was due to microorganisms activities. The surface a)

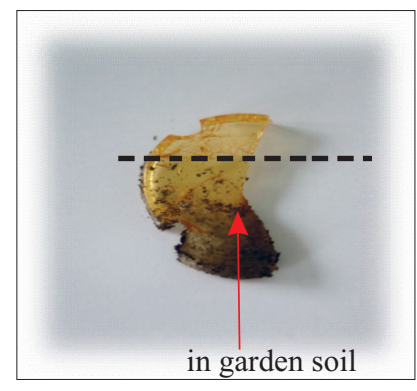

b)

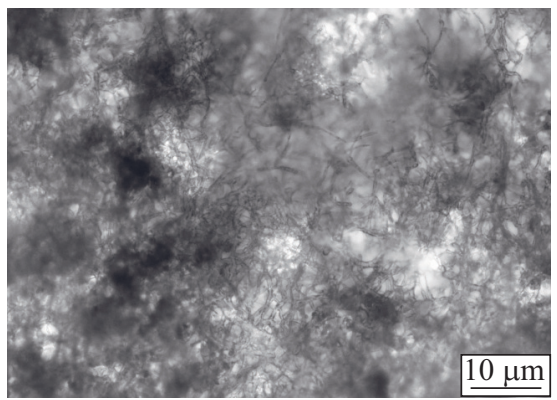

c)

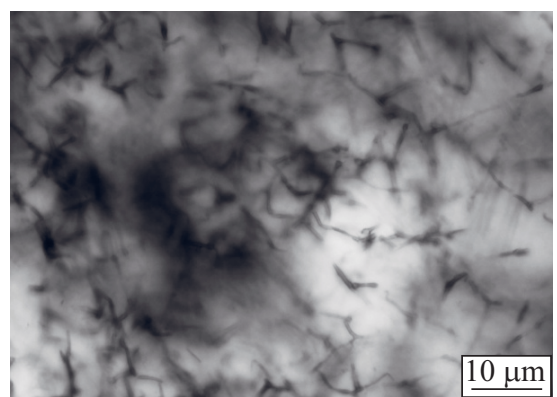

Fig. 2. PAA/D sample: a) placed in half in a garden soil for 6-month, after its removal; microscopic picture: b) before; c) after 6 months of deposition in a soil 
a)

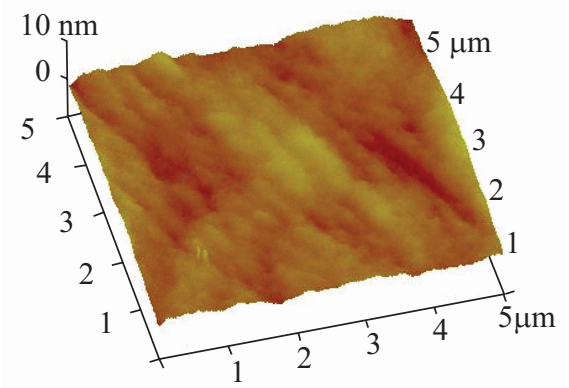

b)

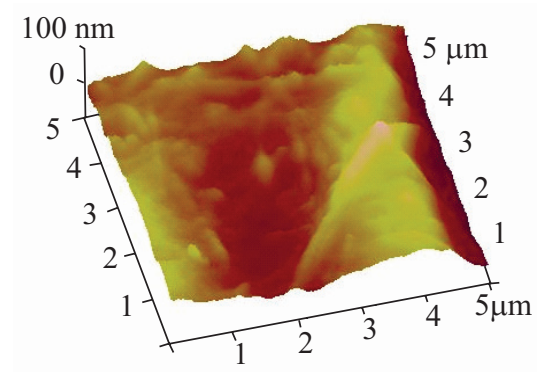

Fig. 3. AFM pictures of PAA/D samples: a) before degradation, b) after 6 months of biodegradation

roughness of the initial not degraded PAA/D sample expressed by the RMS (root-mean-square) roughness indicator is much smaller (RMS $=1 \mathrm{~nm}$ ) than on the sample which underwent the partial biodecomposition (RMS = $26 \mathrm{~nm}$ ) (see also the differences in the z-scale).

Consequently, the increase in roughness gives evidence for the growing decomposition of the sample, where by the significant development of the surface it enhances the adsorption of water together with enzymes produced by microorganisms. Thus the efficiency of degradation is being increased $[15,16]$.

Structure investigations were performed by means of the Raman spectroscopy of the initial (not degraded) PAA/D sample and of the same after the 6-months biodecomposition (Fig. 4).

The polymer composition containing PAA and D exhibits characteristic bands for both components (Fig. 4, spectrum a). The Raman spectrum analysis confirmed the presence of groups characteristic to carboxylic acids [from PAA formula (I)] in at $1723 \mathrm{~cm}^{-1}$ corresponding to stretching vibrations of the carbonyl group $-\mathrm{C}=\mathrm{O}$, while in a lower range of bands at around $1258 \mathrm{~cm}^{-1}$ occur stretching vibrations of $\mathrm{C}-\mathrm{O}$ and deformation vibrations of the group C-O-H [from D, formula (II)].

Consequences of the biodegradation result in an increase of the absorption band which is related to $-\mathrm{OH}$ stretching vibrations $\left(3700-2900 \mathrm{~cm}^{-1}\right)$, evidenced in Fig. 4, spectrum b. This fact is stemps from the hydrophilicity of the sample being degraded. Adsorption of water stimulates the hydrolysis process which favors biodegradation.

The absorption band corresponding to $\mathrm{C}=\mathrm{O}$ vibrations (characteristic to carboxylic acids, $1723 \mathrm{~cm}^{-1}$ ) fades out, while new bands are formed: 1645 and $1568 \mathrm{~cm}^{-1}$ corresponding to deforming vibrations of $\mathrm{C}-\mathrm{O}-\mathrm{H}$ and $\mathrm{C}-\mathrm{O}$ and to asymmetric deforming vibrations of $\mathrm{COO}^{-}$, respectively. These changes can be the result of superimposing vibrations related to the decomposition of certain groups, within the functional group, and to formation of new

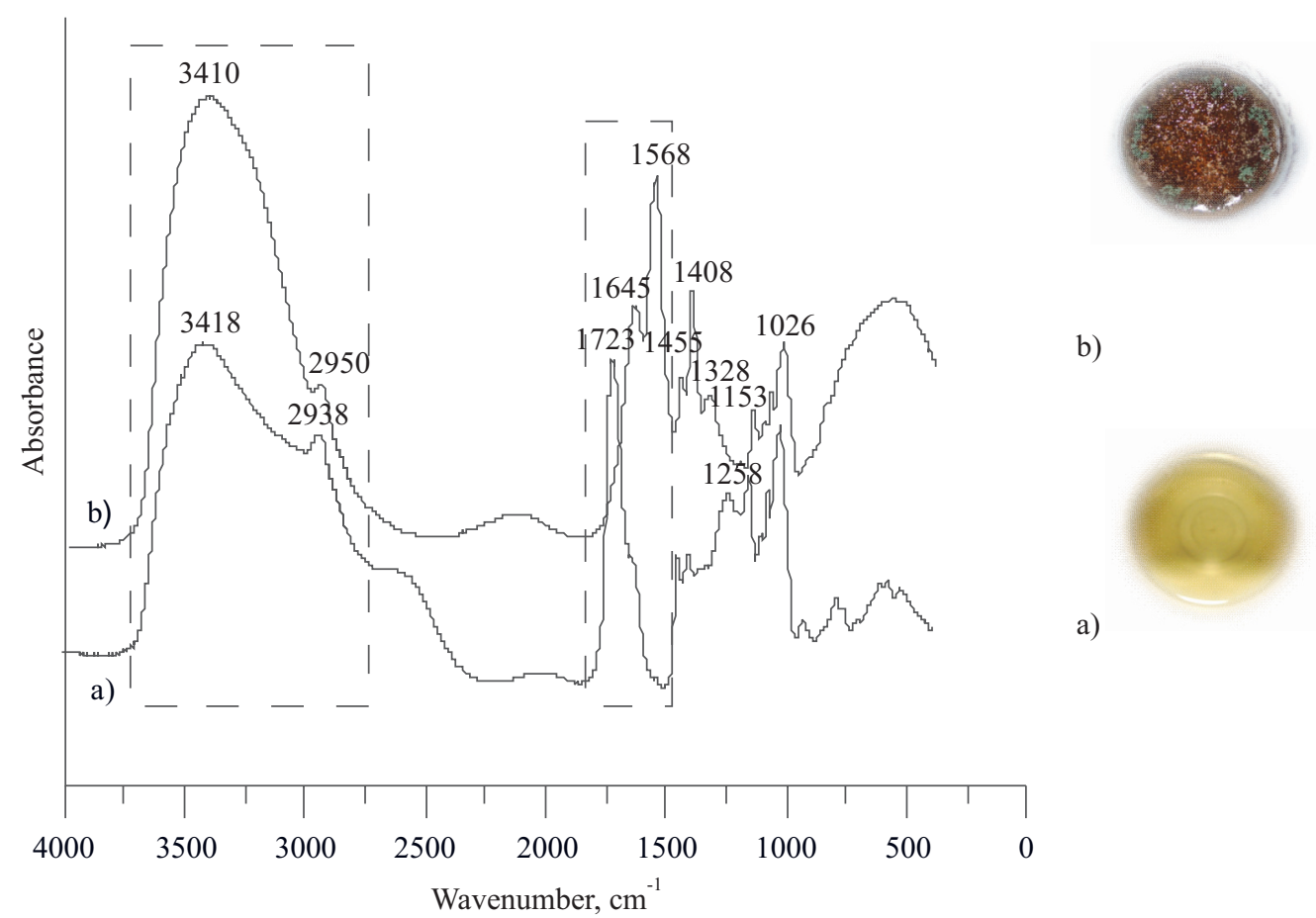

Fig. 4. Raman spectra of: a) polymer composition PAA/D before the biodegradation, b) polymer composition PAA/D after 6 months of biodegradation 
bonds during the biodecomposition. Changes in the range of $1600-1500 \mathrm{~cm}^{-1}$ can be also seen.

The increase in intensity of the bands and appearance of bands characteristic to-OH vibrations can be a result of chain breaking, as well as the formation of new ones thus making the attack of microorganisms easier. The fact that during the process of biodegradation adsorption of water takes place on the surface of the sample is clearly evidenced by the AFM pictures. The inner layers of the polymer bring about the biochemical decomposition $[15,16]$.

\section{CONCLUSIONS}

Doubtlessly, the biodegradation process of foundry polymer binders effected the influence of microorganism is quite complex. On one side the chemical constitution of the binder appeared to be important (due to the presence of polar groups: hydroxyl and carboxyl), and on the other side the way and conditions of carrying out the process are significant (mineral nutrients, suitable oxidation degree, humidity, optimal temperature, maintaining $\mathrm{pH}$ levels).

It was found that the method designed for analyzing the biodegradation process of materials in an aqueous environment (Zahn-Wellens static test) can also be adopted for determining the degree of biodegradation $\left(R_{t}\right)$ of the polymeric foundry binders.

Basing on results obtained for the chemical oxygen demand (COD) it was possible to estimate the progress of the biodegradation of a binder provided by a poly(acrylic acid)/dextrin (PAA/D) composition.

This binder has been subjected to a gradual biodecomposition which after 28 days of testing achieved the degree of biodegradation $R_{t}=65 \%$. Such a value refers in accordance with reference date to a biodegradability regarded to be total. From Raman spectra, as well as from microscopic pictures the conclusion results that the gradual decomposition of the polymeric binder was affected by humidity and other moieties contained in the soil.

Both components of the polymeric PAA/D binder contain in their structures hydroxyl and carboxyl functional groups which are susceptible to biodegradation due to the poly(acrylic acid) and the dextrin can undergo a hydrolytic decomposition accompanied by chain scissions which result in the formation of low molecular weight products (monomer, dimer). In the first order microorganisms attack the dextrin since glycoside bonds are the more susceptible to scissions, and in fact the dextrin belongs to those polymers which undergo a complete biodegradation. It is to recognize, however that despite the content of carboxylic group in the structure the poly(acrylic acid) as polymer does not suffer a complete biodegradation because of its bacteria static properties.

The results obtained during the realization of the reported investigations can constitute the basis to undertake further works on the biodegradation of organic binders applied in the foundry industry. They also provide useful information on the possibility and proceeding of the decomposition of binding materials under storing conditions on dumping grounds.

\section{REFERENCES}

1. Lewandowski J. L.: „Tworzywa na formy odlewnicze”, Akapit, Warszawa 1997.

2. Holtzer M., Podrzucki Cz., Dańko R.: Dokument Referencyjny: „Najlepsze dostępne techniki w kuźnictwie i przemyśle odlewniczym", Komisja Europejska 2005.

3. Chanda M., Roy Salil K.: „Industrial Polymers, Specialty Polymers and Their Applications", CRC Press, Taylor \& Francis Group 2008.

4. Eastman J.: Modern Casting 2000, 10, 32.

5. Zhou X., Yang J., Qu G.: J. Mater. Process. Technol. 2007, 183, 407.

6. Patterson M., Thiel J.: „Developing Bio-Urethanes for No-Bake", Foundry Manage. Technol. 2010, June 1.

7. Holtzer M.: Arch. Foundry Eng. 2003, 9, 189.

8. Grabowska B.: Arch. Foundry Eng. 2009, 9, 41.

9. Grabowska B.: Polimery 2009, 54, 507.

10. Grabowska B., Holtzer M., Górny M., Dańko R., Grabowski G.: Arch. Foundry Eng. 2011, 11, 47.

11. Gołębiewski J., Gibas E., Malinowski R.: Polimery 2008, 53, 799.

12. Kaczmarek H., Bajer K.: Polimery 2008, 53, 631.

13. Żuchowska D., Steller R., Meissner W.: Polimery 2007, 52, 524.

14. Mucha M.: „Polimery a ekologia”, Wydawnictwo Politechniki Łódzkiej, Łódź 2002.

15. Swift G.: Polym. Degrad. Stab. 1998, 59, 19.

18. Fenyvesi E., Gruiz K.: Chemosphere 2005, 50, 1001. 